\title{
Performance, Documentary, and the Transmission of Memories of the Great Leap Famine in the Folk Memory Project
}

\section{Judith Pernin}

\section{(2) OpenEdition Journals}

Electronic version

URL: http://journals.openedition.org/chinaperspectives/6572

DOI: $10.4000 /$ chinaperspectives. 6572

ISSN: 1996-4617

\section{Publisher}

Centre d'étude français sur la Chine contemporaine

\section{Printed version}

Date of publication: 25 November 2014

Number of pages: $17-26$

ISSN: 2070-3449

\section{Electronic reference}

Judith Pernin, «Performance, Documentary, and the Transmission of Memories of the Great Leap Famine in the Folk Memory Project », China Perspectives [Online], 2014/4 | 2014, Online since 01 January 2017, connection on 28 October 2019. URL : http://journals.openedition.org/ chinaperspectives/6572; DOI : 10.4000/chinaperspectives.6572 


\title{
Performance, Documentary, and
}

\section{the Transmission of Memories of \\ the Great Leap Famine in the Folk}

\section{Memory Project}

\begin{abstract}
Independent documentary film projects dealing with history have recently multiplied in China. While all seek to shed new light on personal experiences of the Mao era, they vary greatly in form, method, and scale. Launched in 2010 by Wu Wenguang at the Caochangdi Workstation, a space devoted to contemporary dance and documentary film, the Folk Memory Project aims at producing various textual and visual records of the historical experience of rural populations, especially during the Great Leap famine. Of special interest are the 20 documentaries of the Folk Memory Project's film section - a body of works constantly growing following yearly returns by filmmakers to their "home" villages. These films are characterised by a performative aspect that is rare in other Chinese documentaries on similar topics. This contribution examines this body of documentaries and the role of performance and performativity in the recording of collective memory of the famine.
\end{abstract}

KEYWORDS: Performance, memory, documentary film, Great Leap famine, Wu Wenguang.

ndependent documentary film projects dealing with history have recently multiplied in China. While all seek to shed new light on personal experiences of the Mao era, they vary greatly in form, method, and scale, ranging from individual films relying on investigation and interviews (1966, My Time as a Red Guard, Wu Wenguang, 1992, 165 min.; Though I am Gone, $\mathrm{Hu}$ Jie, 2006, 70 min.), to minimalist filmic memoirs (He Fengming, Wang Bing, 2007, 186 min.), and scholarly participative documentary videos such as the Hundred People, Hundred Years micro documentaries of the magazine Our History. ${ }^{(1)}$

Launched in 2010 in Caochangdi Workstation (Caochangdi Gongzuozhan), a space dedicated to contemporary dance and documentary film, the Folk Memory Project (Minjian Jiyi Jihua, thereafter FMP) was initiated by independent documentary filmmaker Wu Wenguang and his partner, choreographer and Living Dance Studio director Wen Hui. It is a collective performing arts and documentary film project focusing on memories of the Great Leap famine (1959-61) (2) in the countryside. The lack of appropriate recognition of the Great Leap famine in Chinese official history, as well as the urgency of recording the survivors' memories, prompted this independent project and weighed on its general outline. As the disaster was nationwide, the FMP was conceived as a large-scale participative project open to all. While individuals from various backgrounds participate more or less regularly in the FMP activities, its core team is composed of seven young artists in residence (Zhang Mengqi, Luo Bing, Shu Qiao, Zou Xueping, Li Xinmin, Wang Hai'an, and Guo Rui). (3) To record the villagers' historical memories, they regularly go back to their "home villages," (4) initially spending a couple of weeks to around three months in winter 2013-2014. After each round of fieldwork, they edit their footage into feature-length documentaries ${ }^{(5)}$ and work on collective and individual performance pieces inspired by this ex-

This article is the result of several fieldtrips, workshops, and exchanges with the Caochangdi Workstation artists in residence. An earlier version of this text was presented at the 2014 AAS Conference in Philadelphia. I would like to thank Sebastian Veg and two anonymous evaluators for their careful reading and suggestions, as well as the Caochangdi Workstation residents for their time and patience. This research was undertaken as part of the program "New Approaches to the Mao Era (1949-1976): Everyday History and Unofficial Memory," jointly funded by the Agence Nationale de la Recherche (ANR; France) and the Hong Kong Research Grants Council (RGC).

1. These are part of the Citizen Memory Project (Gongmin jiyi jihua) launched in 2013 by the magazine Our History and the New History Cooperative (Xin Lishi Hezuoshe). See their blog: http://ourhistory.blog.21ccom.net (accessed on 12 September 2014).

2. The period's name and chronology differ according to authors and their stance on official history. In Yang Jisheng's Tombstone (Hong Kong, Cosmos Books, 2008) and the introduction to the English version by Edward Friedman and Roderick Mac Farquhar (New York, Macmillan, 2012), it spans the years 1958 to 1962, as in Zhou Xun, The Great Famine in China, 1958-1962: A Documentary History, New Haven, Yale University Press, 2012. In official histories, it is more commonly referred to as the 1959-1961 "Three years of hardship" (San nian kunnan shiqi). On the Caochangdi Workstation blog, it is referred as the 1959-1961 "Three Years of Hunger" (San nian ji'e).

3. They also joined or left the project at different dates. For a detailed description of the FMP, see Wu Wenguang, "Minjian jiyi jihua zhong de da jihuang jilupian," Ershiyi Shiji, No. 142, April 2014, pp. 104-117. A translated version appears on pp. 37-44 of this issue.

4. These young filmmakers' sense of belonging to the countryside differs as much as their educational and social backgrounds: some were born and raised in the villages and only became "urbanised" after attending university (Zou Xueping); others have only their grandparents left in the village and were raised in middle-sized cities. High-school dropout Li Xinmin could be considered a migrant worker and maintains strong ties to her rural background in Yunnan; Zhang Mengqi has no direct connection to the countryside or her estranged father's village in Hubei.

5. Most of the films are around 70 minutes long, except for those of irregular (non-resident) filmmakers outside the scope of this article. See the filmography p. 44. 
perience. ${ }^{(6)}$ Besides these two main forms of creative output, they also contribute to a dedicated blog ${ }^{(7)}$ and other social media platforms, posting transcriptions of full-length interviews with villagers, still pictures, and documentary writing in the form of diaries and production notes. Other Caochangdi Workstation residents, namely Wen Hui, Wu Wenguang, and Villager Self-Governance Film Project participant Jia Zhitan, ${ }^{(8)}$ have also carried out similar work. ${ }^{(9)}$ All of them occasionally conduct workshops with university or secondary students throughout China, often inspiring members of their audience to carry out oral history interviews in their own villages. ${ }^{(10)}$

Because of its multifaceted aspects, the great amount of archival material and artistic works produced, and its wide-ranging scale, the FMP presents itself as a total project combining various disciplines spanning both the arts and the social sciences. The core participants' documentary films are equally hard to categorise cinematically, and their aesthetics - a distinctive mix of unsteady shots and descriptive sequences, short interviews, and participative scenes - is often perplexing for the audience, even though the authors' dedication and historical awareness always receive well-deserved praise. Consisting mainly of interviews about the Great Leap Forward, these films fit in the subgenre of "historical documentary," but since they are collectively produced, they could also count as participatory videos ${ }^{(11)}$ aimed at raising awareness on past and contemporary problems faced by rural populations. Of equal importance are their first-person accounts of the experience of young "urbanised" people returning to the countryside, which brings them closer to film diaries or family films.

Distinctively, this subjective mode incorporates various performative elements that set them apart from other Chinese independent historical documentaries. The filmmakers' use of various devices pertaining to the realm of performativity and performance arts in a large sense is consistent with Wu Wenguang and Wen Hui's multidisciplinary approach. Caochangdi Workstation projects have always blended performance and documentary, for instance by mixing documentary video footage and onstage performances in the Living Dance Studio's works or in the film productions, by observing performers' lives and struggles on the road, ${ }^{(12)}$ or the ongoing creation of a performance piece with migrant workers. ${ }^{(13)}$ To some extent, this interplay between documentary and performance, and the historical theme of the Folk Memory Project, derive from Wen Hui's approach to contemporary dance and theatre and is itself informed by the documentary theatre genre. ${ }^{(14)}$ The pieces Remembering 1 (Huiyi yi, 2008) and Report on Body (Shenti Baogao, 2002) ${ }^{(15)}$ touch upon historical matters and use remembrance and documents as primary materials. Except for these onstage precedents, the Folk Memory Project's films are Caochangdi Workstation's first cinematic attempt to directly deal with the issue of historical memory. More than just a change of medium, this shift to a documentary film practice has generated a whole new set of questions regarding oral history, performance, and the representation and transmission of memory. Since performance is disappearance, this "weaving together of two sets of xianchang (on-site or on-the-scene events)" (16) reaches another level of significance when it is related to the topic of historical memory, combining the performance's impermanence with the archival function of the recording. ${ }^{(17)}$

Performativity has been widely discussed in documentary cinema studies since the 1980s, and recent historical films such as Rithy Panh's S21 The Khmer Rouge Killing Machine (2003, 101 min.) - or more recently yet in The Act of Killing (Joshua Oppenheimer et al., 2012, 160 min.) - use performativity as a working method to retrieve forgotten or repressed histories and confront perpetrators. In these works, performativity is generally con- ceived as re-enactment, although it can also appear in less obvious and more spontaneous forms such as imitation or quotes, usually emerging during onsite interviews. ${ }^{(18)}$ In Chinese historical documentaries, this mode of interaction with the filmed subjects remains rare, even in recent independent works, where filmmakers tend to focus on victims or witnesses instead of perpetrators, and devote more attention to the seemingly spontaneous and direct recording of unofficial memory through interviews or informal conversations. ${ }^{(19)}$ Indeed, at first sight, performativity does not seem necessary to record oral history, especially when people are willing to testify. The fact that performative modes are predominant in the above-mentioned Cambodian and Indonesian examples certainly has a lot to do with the choice of perpetrators as filmed subjects. ${ }^{(20)}$ Conversely, the fact that other modes of interaction with witnesses of history, such as conventional interviews, observational shooting, and the editing of visual archives, are more commonly found in Chinese independent documentaries seems related to the filmmakers' and filmed subjects' shared awareness of the need to produce historical narratives grounded in ordinary people's experiences, thus counteracting the official version. In this context of common understanding, and in this non-official framework (minjian), resorting to performance or performativity seems unnecessary save for expressive purposes, or if the filmed subjects are reluctant or unable to testify. In fact, regarding the Folk Memory Project, the viewer has grounds to question the very efficacy of a performative method, since most of the historical information in the FMP's films is explicitly delivered in interview sequences devoid of performative elements rather than in those displaying a higher degree of performativity. Why, then, do these films use performativity, and what can we understand

6. For a discussion of the performance works, see Zhuang Jiayun, "Remembering and Reenacting Hunger: Caochangdi Workstation's Minjian Memory Project," The Drama Review, Vol. 58, No. 1, February 2014, pp. 118-140

7. http://blog.sina.com.cn/u/2181292250 (accessed on 30 June 2014).

8. The Village Self-Governance Film Project (Zhongguocunmin zizhi jihua) is another participative initiative launched in 2005 by Caochangdi Workstation, aimed at facilitating self-produced documentaries on rural elections and more broadly on issues affecting the countryside. See for instance Matthew D. Johnson, "Bringing the Transnational Back into Documentary Cinema: Wu Wenguang's China Village Documentary Project, Participatory Video and the NGO Aesthetic," in China's iGeneration: Cinema and Moving Image Culture for the Twenty-First Century, London, Bloomsbury, 2014, pp. 255-81. See also, in French, my interview with Wu Wenguang: "Wu Wenguang, Filmer l'imprévisible," Monde Chinois, No. 14, 2008, pp. 28-34.

9. See the filmography p. 44.

10. Other collaborators occasionally join their activities, providing input in the form of films, performance pieces, oral history, or discussions.

11. See, for instance: Shirley White, Participatory Video: Images that Transform and Empower, New Delhi, Sage, 2003

12. For instance Wu Wenguang's 1999 film Jiang Hu: Life on the Road, (Jianghu), $120 \mathrm{~min}$.

13. Dancing with Farmworkers (He mingong tiaowu), 2002, 57 min.

14. This genre is based on the use of pre-existing documents (reports, interviews, and so on) as performance materials and originates in the works of 1920s German authors such as Berthold Brecht and Erwin Piscator.

15. See Zhuang Jiayun, "Remembering and Reenacting Hunger," art. cit., p. 125

16. Ibid., p. 132.

17. See Peggy Phelan, "The ontology of performance: Representation without reproduction," in Unmarked:The Politics of Performance, London, New York, Routledge, 1993, pp. 146-167.

18. Claude Lanzmann's Shoah (1985, $613 \mathrm{~min}$.) gives a wide array of examples of this attenuate form of reenactment. See, in French, "Le lieu et la parole, Interview des Cahiers," in Bernard Cuau (ed), Au sujet de Shoah: le film de Claude Lanzmann, Paris, Belin, 1990, pp. 292-299, initially published in Les Cahiers du cinéma, No. 374, July-August 1985.

19. Except in a very subtle form, such as in Wu Wenguang's 1966, My Time as a Red Guard.

20. For a discussion on Rithy Panh's "perpetrator documentaries," see Raya Morag, "The Survivor-Perpetrator Encounter and the Truth Archive in Rithy Panh's Documentaries," in Camille Deprez and Judith Pernin (eds), Post-1990 Documentary: Reconfiguring Independence, Edinburgh University Press, forthcoming, 2015. See also: Joram Ten Brink and Joshua Oppenheimer (eds), Killer Images: Documentary Film, Memory, and the Performance of Violence, New York, Columbia University Press, 2013. 
from these sequences, especially in a context of antagonism between official and minjian history?

This article seeks to answer these questions by focusing on the documentaries made by the young filmmakers of the FMP. Drawing on recent debates on performance, performativity, and documentary and on the specificity of the Caochangdi Workstation's productions to combine documentary and performing arts, I will show where and how performance plays a role in the recording and the representation of collective memory of the famine in this body of films. This article does not intend to deal with the historical matters themselves, but rather to examine how independent filmmakers investigate historical questions, and how documentary practice combines with performative elements in this project. This will allow us to reconsider concrete issues around the use of performance and performativity in documentary, which constitute a lively debate in today's creative and academic circles.

\section{A collective work method}

Before examining the films in question, the work method of the FMP core team should be properly described. Initially focusing on the topic of the Great Leap famine, the Folk Memory Project has seen a dramatic evolution in its scope and themes, a move closely linked to the specific work method of the artists in residence. For most of the year, Wu Wenguang, Wen Hui, Jia Zhitan, and the young filmmaker-performers share the same living and working space in a Beijing suburban village. (21) Their work routine is divided between performing arts and documentary film with morning physical exercises, performance rehearsal, presentation of fieldworks findings and footage, and editing work. During thematic workshops or on a daily basis during the collective meals, formal or informal discussions of their activities and the overall direction of the project are conducted. Thus, they have regular exchanges on their fieldtrips and the artistic productions inspired by experiences in the countryside. These discussions are often the launching ground for new subprojects or participative activities designed to interact more effectively with the villagers and to engage them further with the project. Some village children thus joined the filmmakers in conducting interviews, and with the help of some inhabitants they have achieved other apparently unrelated projects such as opening village libraries or collecting garbage. Since the filmmakers felt uncomfortable interviewing elderly people about the past when their current living conditions were less than acceptable, they decided to improve assist them in daily tasks. They also established an "elderly fund" (laoren jijin) to facilitate the purchase and distribution of basic household items, medicine, and food.

Crossing over various artistic media, this participative documentary project encompasses performance (xingwei) and action (xingdong) to alleviate pressing issues faced by villagers. In the long run, this aspect helped the filmmakers in their relationships with people who were not necessarily willing or ready to testify. So, instead of being fragmented endeavours, these various actions and productions complete one another: oral history recordings become feature length films or blog posts, and interactions between the various protagonists translate into filmic representations or onstage performances. ${ }^{(22)}$ The FMP is also characterised by a heuristic approach, since the core participants mutually review their actions on a regular basis, and correct them upon their return to the village. This work method has fostered practices of appropriation and borrowing between the members, as much in terms of initiatives (for instance opening libraries) as of topics, modes of representation, and film forms. The resulting works (texts, films, and plays) are therefore incredibly intricate and mutually dependent on one another, as Zhang Jiayun has noted. ${ }^{(23)}$ The performance pieces are inspired by the fieldwork, the actors appropriating their filmed subjects' memories through the mediation of their own bodies in a sort of transgenerational onstage "re-enactment."

\section{Performance, documentary, and memory}

Elaborated alongside performance pieces in their own right, the FMP documentaries stand against a complex theoretical background regarding the issues of performance and performativity. General definitions of the English term "performance" refer to a wide range of notions such as behaviour and efficiency, and also to actions being accomplished or already completed, to the fulfilment of a promise, and finally to theatrical acting and public representations. This wealth of signification has prompted the adoption of the term in research areas spanning social sciences to linguistics, art, and film studies. (24) For documentary cinema, this term proves quite challenging, since "non-fiction" films represent what Bill Nichols terms "the desire for performance that is not performance." (25) With its implicit reference to theatrical acting, this phrase translates the conceptual unease faced by theoreticians when dealing with nonfictional productions, namely the issue of authenticity and truth, a question even more crucial when films deal with historical matters. The difficulty of drawing a line between the documentary protagonist and the fiction film actor has inspired Bill Nichols to coin the expression "virtual performance" to define the documentary filmed subjects' "unscripted and unrehearsed performance, which, like a scripted and rehearsed one, carries significant themes through bodily gesture, tone of voice and facial expression." (26) This somewhat vague definition - since the degree of preparation of these "performances of a lifetime" (27) is impossible to evaluate - nevertheless points quite aptly at the impression of theatricality conveyed by some larger-than-life documentary filmed subjects.

As 1980s documentary filmmakers started to occupy centre stage in their own works, the same scholar added the "performative mode" to his widely accepted categorisation of documentary films. ${ }^{(28)}$ Indeed, the other modes (poetic, expository, participative, reflexive) did not quite correspond to this new tendency to "give added emphasis to the subjective qualities of experience and memory that depart from factual recounting." (29) The performative mode involves a subjective and emotional participation of the filmmaker in the film ${ }^{(30)}$ by using first-person narration, by displaying the intimacy of filmmaker and filmed subject, or by combining actual and imag-

21. As of September 2014, due to rising rent, the Caochangdi Workstation's residents have moved to another location further out in the Beijing suburbs.

22. For a detailed description, see Zhuang Jiayun, "Remembering and Reenacting Hunger," art. cit., pp. 129-130.

23. Ibid.

24. For instance, the classics of Erving Goffman, The Presentation of Self in Everyday Life, Garden City, N.Y., Doubleday, 1959; and John Langshaw Austin, How to Do Things with Words, Harvard, Harvard University Press, 1975

25. Bill Nichols, Representing Reality: Issues and Concepts in Documentary, Bloomington, Indiana University Press, 1991, p. 121.

26. Ibid., p. 122.

27. Ibid.

28. Bill Nichols, Introduction to Documentary (second edition), Bloomington, Indiana University Press, 2010.

29. Ibid., p. 131.

30. See Bill Nichols, Blurred Boundaries: Questions of Meaning in Contemporary Culture, Indiana University Press, 1994, pp. 94-99. 


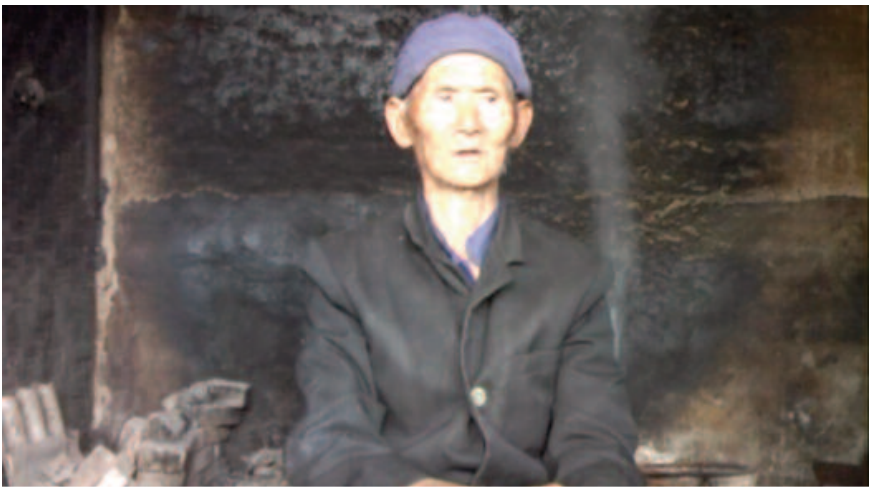

on the co-authorship at work in various performative Chinese documentaries. ${ }^{(36)}$

However, the FMP films differ from these examples of "performative" Chinese independent documentaries focused on performance arts or private contemporary issues in that they are fundamentally related to memory and historical topics, something that Nichols recognised as a defining trait of this particular mode. Memory is indeed often crucial in the examples he gives. Tongues Untied (Marlon Riggs, 1989, 55 min.), Paris is Burning (Jennie Livingston, 1990, 71 min.), and Frantz Fanon: Black Skin, White Mask (Isaac Julien, 1996, 70 min.) display the filmmakers' or the filmed subjects' personal experiences, stressing that knowledge is questionable or ambiguous. But, if the FMP films deal with memory through performativity, the young filmmakers are mostly collecting the personal past experiences of an older generation and not their own, and without questioning their stories. Thus, on several levels, the FMP films differ from Nichols's definition as well as from other Chinese performative documentaries. Besides a general tendency toward the performative mode, the FMP films make use of other channels of theatricality and subjectivity, such as actual performance pieces or small acting scenes performed by the filmmaker, which are edited together sometimes within a single sequence. In any case, the performativity seems mainly to characterise the FMP filmmakers, whereas historical memory is expressed without performativity by the witnesses, in interviews or conversations. As Anne Jerslev notes, (37) although useful, the existing literature on performance and performativity in film studies offers a vast array of definitions, sometimes blurred or inconsistent, originating in the semantic wealth of the term "performance."Therefore, analysing the use of performance in this body of works requires distinguishing between different "performative" elements in order to understand what they achieve in terms of the project's historical ambitions.

\section{Interviews, oral history, and virtual performances}

Before dealing with this issue, let us examine the sequences that are the most visibly tied to historical memory, namely the interviews, and compare them to similar oral history fieldwork.

Images 1-A, 1-B, 1-C - Li Guangzu's discourse on PLA accomplishments in Li Xinmin's Huamulin, Boy Xiaoqiang (2013, 76 min.). (C) Li Xinmin

ined or staged elements. Nichols' categories have spurred many theoretical elaborations. Some scholars such as Stella Bruzzi go so far as suggesting that performance is an ontological trait of documentary, thus challenging the accepted definition of this film form as non-fictional and non-theatrical. (31)

China scholars also refer to these theories in their analyses of independent documentaries, stressing that they differ from official expository films in their display of subjectivity or in their interest in theatre and performance art. ${ }^{(32)}$ Charles Leary's discussion on The Other Bank (Bi'an, 1995, 140 min.), Jiang Yue's documentary on the rehearsal of Mou Sen's creation of Gao Xingjian's play, foregrounded the intricate relationship between performers and documentary filmmakers. (33) Referring to Zhao Liang and Cui Zi'en's films, Paola Voci noted "performance itself [...] becomes a key to displaying marginalized realities, including those of the documentarian." (34) Ying Weiwei's The Box (Hezi, 2001, 86 min) was also analysed in reference to Bill Nichols' performative mode for the filmmakers' subjective position towards her filmed subjects at once living and performing their love on screen, (35) and ethical and professional issues were raised in Wang Yiman's discussion

31. See Stella Bruzzi, New Documentary: A Critical Introduction, London, Routledge, 2000; and a critical appraisal of the book's main theory: Anne Jerslev, "Performativity and Documentary: Sami Saif and Phi Ambo's Family and performativity," in Rune Gade and Anne Jerslev, Performative Realism: Interdisciplinary Studies in Art and Media, Copenhagen, Museum Tusculanum Press, 2005, pp. 85-112.

32. See for instance: Bérénice Reynaud, "Dancing with Myself, Drifting with My Camera:The Emotional Vagabonds of China's New Documentary," Senses of Cinema, 2003, http://archive.sensesofcinema.com/contents/03/28/chinas_new_documentary.html (accessed on 12 September 2014); Wang Qi, "Performing Documentation: Wu Wenguang and the Performative Turn of New Chinese Documentary," in Zhang Yingjin, A Companion to Chinese Cinema, Chichester, Wiley-Blackwell, pp. 299-318; and Judith Pernin, "Xingwei, kongjian yu xingdong. Youguan yishujie de liang san ge jilupian" (Performance, space and action: Two or three documentaries about the art world), trans. by Zhang Yi, Dianying Zuozhe, No. 5, December 2013, pp. 221-226

33. Charles Leary, "Performing the Documentary, or Making It To the Other Bank," Senses of Cinema, July 2003, http://sensesofcinema.com/2003/feature-articles/performing_documentary/ (accessed on 1 July 2014).

34. Paola Voci, "Blowup Beijing:The city as a twilight zone," in Chris Berry et al. (eds), The New Chinese Documentary Film Movement, op. cit., p. 101.

35. Zhang Yingjin, Cinema, Space, and Polylocality in a Globalizing China, Honolulu, University of Hawaii Press, 2009, pp. 103-170.

36. Wang Yiman, 'II Am One of Them' and 'They Are My Actors': Performing, Witnessing, and DV Image-Making in Plebian China," in Chris Berry et al. (eds), The New Chinese Documentary Film Movement, op. cit., pp. 217-36.

37. "Performativity and Documentary: Sami Saif and Phi Ambo's Family and Performativity," in Rune Gade and Anne Jerslev, Performative Realism: Interdisciplinary Studies in Art and Media, Copenhagen, Museum Tusculanum Press, 2005, pp. 85-112. 
Generally speaking, the FMP films vividly illustrate the challenges of oral history projects: the witnesses are at times sick or are unable to talk or to communicate with the filmmakers because of hearing difficulties or dialect incomprehension. Intermediaries between the filmed subjects and the filmmakers are at times needed to facilitate their exchanges, ${ }^{(38)}$ or simply to be favourably introduced and ensure cooperation. However, some witnesses refuse to talk for fear of reprisal, because they are ashamed, ${ }^{(39)}$ because "it is not important" or painful, or because the situation is "better now" and there is no need to dwell on the past. Paradoxically, some of those who invoke today's achievements in fighting poverty are living in very precarious conditions to say the least. In such cases, nothing can be learnt about the Great Leap famine, only how much the protagonists' past experiences have impacted their discourse. Some interviewees express gratitude for their present situation and look at past "bitterness" as a necessary evil, thus raising a parallel with suku ("speaking bitterness"). This ideological narrative mode denouncing past injustices and praising present accomplishments was in vogue during the witnesses' youth and probably had an impact on their expression of feelings. ${ }^{(40)}$ There is also an important divide based on the witnesses' social background. As Feuchtwang noted of his own field studies: "Those who were cadres at the time, or have been since, tend to repeat the official reasons for the famine even when they give vivid and condemnatory accounts of what happened. ... Those who were not cadres at the time or since seem more prepared simply and openly to blame the top leadership." (41) Sections of these films vividly illustrate this point and the overall persistence of official discourses noted by scholars. Zhang Mengqi's Self-portrait: Dreaming at 47 km (Zihuaxiang: 47 gongli zuomeng, 2013, 77 min.) features a conversation with former brigade chief Liu Qifeng, who gives her a conventional historical account of the New China, conforming to the official rhetoric.

This sequence calls to mind a similar interview in Li Xinmin's Huamulin, Boy Xiaoqiang $(2013,76$ min.) with an old Party member and former soldier, Li Guangzu. Awakened by the filmmaker from a casual nap on the grass, the somewhat eccentric old man invites her into his home to talk freely about the past while his disapproving son is away. Sitting in front of the fireplace, he delivers a slow and dignified speech about the People's Liberation Army's during the past 60 years ${ }^{(42)}$ (images 1-A, 1-B, and 1-C). In the background, the initially imperceptible fire becomes threatening while Li Guangzu monotonously lists the PLA's main generals, praises their accomplishments, and concludes with the general level of happiness in today's society. Contrasting comically with his speech, smoke and flames are bursting behind his back as if this unexpected natural phenomenon were illustrating his ardent words. When he finally stops and gazes blankly at the camera, the fire quickly regresses giving the impression that it was specially engineered. Li Guangzu's eloquence as well as the structure and tone of his monologue convey a sense of theatricality to the sequence, reinforced by the erratic behaviour of the fire. The impersonal character and conformity of his speech to the conventions of official history evokes role-playing more than spontaneity. Here, Li Guangzu offers a former soldier's "virtual performance" that highlights the persistence of rhetorical patterns from the Mao era on the witnesses' discourses. However, the humorous framing of this scene puts this performance in perspective: the bursting flames distract the viewer and break the speech's solemnity in a move similar to another scene also featuring Li Guangzu in Li Xinmin's latest film Huamulin zhi bei (2014, 70 min). This time, after just a few words of Li Guangzu's quasi-identical speech, a child bursts into the frame and starts jumping on his shoulders, stealing his hat, and making faces. Constantly interrupted, the old man's speech loses all its gravitas, giving the viewer the impression that this type of discourse is an act that should not be taken too seriously. Nevertheless, these sequences show the prominence of official narratives over personal memories for some of the interviewees, something that can only be challenged by the filmmakers' practice and choice of mise-en-scene.

Guo Yuhua's findings on the influence of symbolic domination on peasant's memory and modes of expression are of particular interest here, because to a certain extent, they apply to the FMP filmed subjects. ${ }^{(43)}$ Many important events have been erased from the villagers' memories, whereas other details, such as quantities of food, workload, hours of sleep and deprivation are often vivid and accurate, especially in the case of women, who seem to remember more things when "they refer to a bodily or a direct experience." (44) This explains why the FMP filmmakers chose a very simple or "naïve" set of questions to engage conversations with the witnesses ("Do you remember what you ate in 1959?"; "How was it to eat at the canteen?"). In turn, it also explains perhaps why most answers, especially in the early FMP films, are short, fragmentary, and lacking narratives that viewers can relate to. That being said, the protagonists do not necessarily follow the above-mentioned pattern of gender differences, and some interviews are strikingly articulate, accurate, and compelling. In Shu Qiao's Shuangjing Village, I Want to Marry You (Shuangjing, wo yao jia gei ni, 2013, 74 min.), an in-depth interview of an old lady runs through the film; Wen Hui's aunt in Listening to Third Grandmother's Story (Ting San Nainai jiang guoqu de shiqing, 2011, 75 min.) gives an intimate and humorous view on her historical experience, and Luo Bing's films focus mainly on a single character, Ren Dingqi, who not only tells his story orally but has also written his memoirs. Other times, these successful detailed interviews are too long to appear in the films and are transcribed and posted on the FMP's blog. Interestingly, the filmmakers have often decided to show the interview dispositive (the

38. Zhang Mengqi, for instance, relied largely on interpreters in her first film, because she did not easily understand the villagers' dialect, but she picked it up in her later films.

39. Stephan Feuchtwang points out similar feelings in his After the Event: The Transmission of Grievous Loss in Germany, China and Taiwan, London, Berghahn Books, 2011, p. 210.

40. Suku has also been described as a highly performative form of discourse in Ann Anagnost, National Past-Times: Narrative, Representation, and Power in Modern China, Duke University Press, 1997.

41. Stephan Feuchtwang, After the Event, op. cit., pp. 92-93.

42. Below is his four-minute long speech as translated in the subtitles: "I'm Li Guangzu from Baiyun Village. My experience comes from the revolution. Chinese communism is Marxist-Leninist. Maoist thought, Dengism, and Jiang Zemin are the third generation of collective leadership, guiding where we sail. I feel that since the revolution, guerrilla warfare was for the revolution. Workers and farmers, the Red army, were for the revolution. Workers and farmers, the Eight Route Army went on a Long March, climbing over snow-topped mountains, over meadows, persevering in its fight. The New Fourth Army was led by the Chinese Communist Party. Ye Ting was the Corps Commander; Xiang Ying was Assistant Corps Commander. Through the revolutionary war, they matured in many hardships and difficult periods. With the New Fourth Army, and led the establishment, in 1927, on August 1, of the People's Liberation Army, and the Fourth Field Army. The Fourth Field Army, Zhu De was the Chief Commander; the first Battalion Commander Peng Dehuai; the second Battalion commander Liu Bocheng; the Third Battalion Commander Chen Yi; the Fourth Battalion commander Lin Biao. The Chinese Communist Party had seized the power by armed force, and defeated strong enemies. The PLA made great and difficult sacrifices for the people. So that the Chinese people could have peace of mind, and live safely and happily. Today's revolution ended in victory. There was victory. People are living happy, prosperous lives."

43. Guo Yuhua, "Xinling de jitihua: Shaanbei yicun nongye hezuohua de nüxing jiyi," Zhongguo Shehui Kexue, No. 4, 2003, pp. 79-92, available on Ai Sixiang, www.aisixiang.com/data/16601.html, and "Koushu lishi:Youguan jiyi yu wangque" (Oral History: on remembering and forgetting), available on Ai Sixiang, www.aisixiang.com/data/16545.html (both accessed on 10 June 2014). See also the respective English and French partial translations: "Psychological Collectivization: Cooperative Transformation of Agriculture in Jicun Village, Northern Shaanxi, as in the Memory of Women," Social Sciences in China, 2003, pp. 48-61; "'Nous étions comme un feu ardent': la collectivisation des esprits dans les récits des femmes du village de jicun (nord du Shaanxi)," Civilisations, No. 56, December 2007, pp. 43-62.

44. See Guo Yuhua, "Nous étions comme un feu ardent," art. cit., p. 47. 


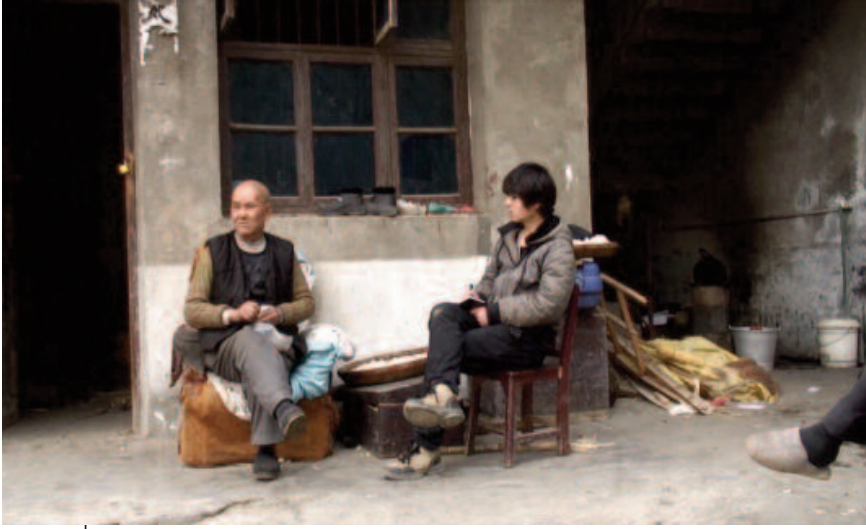

Image 2 - Filmmaker Shu Qiao (right) talks to an elderly villager in Shuangjing Village, I'm Your Grandson (2012, $78 \mathrm{~min}$.). (C) Shu Qiao

encounter with the witness, the setting of the camera, and some preliminary questions) as well as the multiplicity of reactions it creates, rather than the full-fledged "oral history" narratives resulting from the interview. In fact, apart from survivors of the Great Leap famine, other people are featured in the FMP films, and their reactions to the filming process constitute another important focus. Wide generational gaps divide the film protagonists between direct witnesses, their children - who are often indifferent or hostile to the FMP, at least in the beginning - and their grandchildren, who are curious but generally ignorant of the famine. All in all, these documentaries convey the idea that personal memory is hard to retrieve and express: the viewer often sees (especially in the earliest films) a rather impersonal memory of dates, facts, and information, or "virtual performances" transmitting the official discourse on history. That is perhaps why the filmmakers had to turn to performance and performativity themselves, to unlock memories and engage with the witnesses more actively.

\section{Recording memories and displaying subjectivity}

Understood as "different ways of displaying subjectivity," (45) performativity is certainly well represented in the FMP films, especially in their use of the "performative mode." Various elements such as a first-person account delivered by the off-frame voice of the filmmaker, or expressed through photographic self-portraits and direct addresses to the camera emphasise it on the formal level. Besides, many other sequences display casual and personal interactions between the filmmaker and the filmed subject. For these young filmmakers operating in their home village and meeting with relatives or acquaintances, personal interactions are a fundamental part of the shooting process. The predominance of this aspect of the performative mode in their edited films is therefore somewhat expected. Thus, the filmmakers not only expose the documentary protocol, but also their personal relationships with the filmed subjects in family film-like scenes where informal conversations are consciously framed. A recurring shooting dispositive involves setting an otherwise handheld camera into the corner of a room in order to frame together the filmmaker and the filmed subjects. Both are aware of the shooting process, and they talk casually, the filmmaker occasionally leaving the frame to adjust the camera's position (Image 2).

Mixing the trivial and the historical, their conversations are at times devoid of relevant content on the famine, which can be frustrating for some viewers. This is, however, as much a format limitation as a deliberate choice.
Showing memory lapses, repetitive and partial accounts of historical experiences, interference and occasional censuring from relatives during the interviews, ${ }^{\left({ }^{46)}\right.}$ as well as the overall predominance of daily necessities over historical concerns means unveiling a vast array of reactions to the FMP and the different generations' views on such a traumatic and forgotten memory. The evolution of these reactions is actually perceptible in each filmmaker's body of works, as some people initially opposed to the FMP gradually accept and even support it. In Zou Xueping's films, the presence of the camera, handheld or set as described above, often triggers heated arguments with her parents, who disapprove of her involvement in the project, her lack of career prospects, and her lifestyle. Recurring scenes show an irate mother quarrelling with her upset daughter, while her father, a village cadre, silently disapproves. Zou Xueping takes these opportunities to lecture her parents on the project's ambitions and her own. In her subsequent films, although family pressures persist, her father's attitude has changed considerably, since he decides to contribute the sum of 1,000 yuan to the memorial stone Zou Xueping is erecting with the villagers. This evolution is aptly captured and can be read as a sign of gradual acceptance from Zou Xueping's parent's generation. It also testifies to the strength of her determination and to the efficacy of the FMP's pedagogical and participative approach.

The first ten minutes of Wang Hai'an's Attacking Zhanggao Village (Jingong Zhanggao cun, 2012, 86 min.) provide another example of the effectiveness of the performative mode in dealing with witnesses. The film starts with the off-frame filmmaker's voice on a shot of the village's cemetery. After stating his identity, he reveals information about the place, the project, and the people involved. This short monologue is not an edited-in voice over but a direct comment spoken during the shooting, in the mode of amateur films or film diaries. This opening scene is followed by a handheld shot of his walk towards the village, then of his own hands opening the doors of a house. This introduces us to the first encounter with a witness, a lonely but friendly old man, who does not remember much, not even who the filmmaker is. After an unsuccessful exchange of questions with the second interviewee, Wang Hai'an comes closer to him and starts to inquire about his health. His body is now visible in the frame, and his hands start to interact with the breathless old man, stroking his shoulders to make him regain his calm and focus. After a while, the old man starts to describe, in great detail and with personal views, the impact of the Great Leap Forward in his village, and names some of the victims. The progressive editing of this introductory sequence, initially focused on the filmmaker's identity, gives way to highly personal scenes between him and the villagers, signifying that the villagers' memories can actually be retrieved by interacting subjectively and physically with them.

\section{Filming obstacles and performing rural life}

Apart from being an example of the performative mode, this sequence features recurring elements in the FMP films displaying subjectivity or theatricality without being directly used in the recording of memory. Walking

45. Anne Jerslev, "Performativity and Documentary: Sami Saif and Phi Ambo's Family and performativity," op. cit., p. 111.

46. The antagonism of the witnesses' children to the FMP is often featured in this body of film, for instance in Shu Qiao's Shuangjing Village, I Want to Marry You, where an old couple is interrupted in the middle of the interview by their son. The consecutive heated argument is filmed in its entirety by the filmmaker, on frame himself during the whole process. 
scenes filmed in a "subjective camera" mode, staged sequences, shots of opening doors or descriptive and silent scenes inside empty houses appear in many instances in all the participants' films. Rather than dismissing these scenes because they do not seem directly linked to the films' historical ambitions, I would argue that they support the filmmakers' missions. Their repetitive character indicates similar experiences or obstacles encountered in the process of recording memory. Appearing mostly when the interviews are unsuccessful, these transitional shots gain a metaphorical function as the filmmakers' quest for unofficial history. Even though these scenes do not convey the witnesses' memories, they describe the places where they seem embedded, inside their houses and the objects they contain. They are also reminiscent of other exterior sequences describing buildings in use during collectivisation. Often abandoned and almost collapsing, these edifices still bear visible traces of history such as painted slogans lingering on the walls. The implicit meaning of these descriptive sequences is further explored by some filmmakers in staged scenes where spontaneous incidents, subjective experiences, and acting are interlaced. Luo Bing's first film Luo Village: I and Ren Dingqi (Luojiawu: Wo he Ren Dingqi, 2011, 80 min.) starts by a staged sequence where the filmmaker reads aloud his secondary school textbooks, expressing his rejection of official history. Taking place in his house, this sequence evokes other descriptive empty shots in the home of the main character, Ren Dingqi. This man who progressively opens up to the filmmaker has written lengthy memoirs (54 chapters over ten years) looking back at his personal experiences from age four to 70. In Luo Bing's first film, Ren Dingqi calls them an "internal" (neibu) work and refuses to share them. He answers Luo's questions rather reluctantly and only agrees to introduce him to other famine survivors. He is concerned that his testimony could suddenly backfire and bring him trouble as when the Anti-Rightist campaign succeeded the Hundred Flowers movement. Frustrated and intrigued, Luo Bing films inside Ren Dingqi's house, asking aloud where he has hidden his memoirs. It is during one of these scenes that he stumbles upon a pin bearing the inscription "A single spark can light a prairie fire." After a long sequence of empty house shots expressing his hopelessness, this pin sends a somewhat optimistic message that Luo Bing stages at the end of the documentary in a scene where he films himself starting a fire in a field. Materialised by his performance, the pin's prediction becomes true in his second film Luo Village: Pitiless Earth and Sky (Luojiawu: Tiandi wu qing, 2012, 75 min.), since Luo Bing has finally convinced Ren Dingqi to share his memoirs with him. This film is then dedicated to reading, typing, and discussing the manuscript with the other villagers in order to disseminate the old man's historical memories, thus realising the pin's metaphor. Another fire appears near the end of Pitiless Earth and Sky. This time, it is not a staged scene but an accidental arson in an isolated house. Immobile and fascinated, Luo Bing films on while a woman rushes inside to extinguish it, leaving the viewer with mixed feelings about the significance of this recurring symbol. In Luo Bing's two films, staged scenes and spontaneous events are edited together, bringing performativity into the documentary in order to express metaphorically the filmmaker's feeling while attempting to record and circulate someone else's memories.

This combination of fortuitous and staged events appears in other sequences showing the personal and physical engagement of the filmmakers in a theatrical mode. Some of them film themselves performing rural life, imitating the elderly in various agricultural tasks (Image 3). Their acting skills ironically highlight their lack of competence in the countryside. These scenes evoke their onstage performing works, where they re-enact their interviews

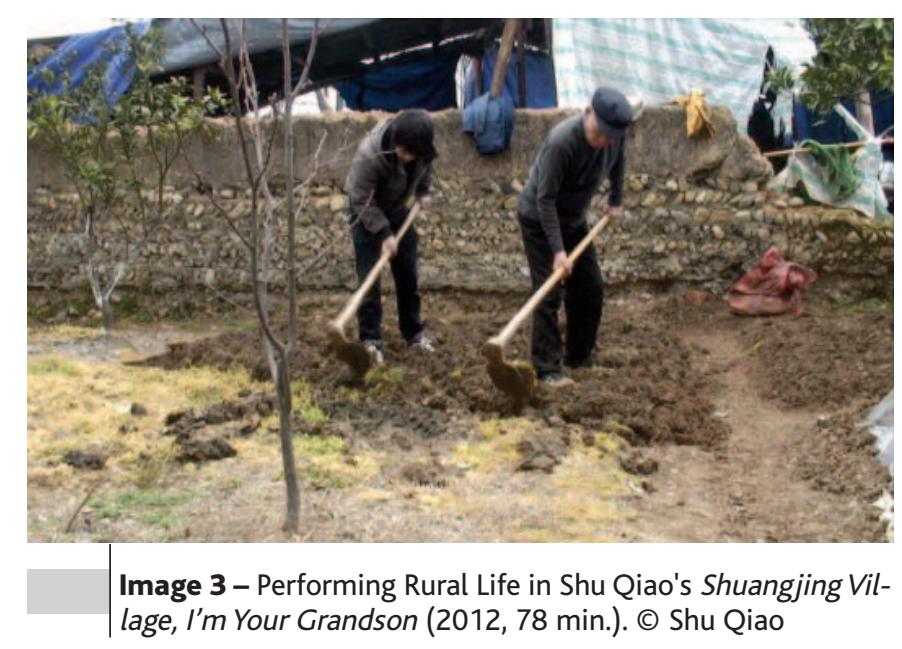

or interactions with elderly villagers, sometimes imitating them in their daily tasks, other times interpreting their memories. Anecdotal as they may seem, these performative sequences in the documentaries show the filmmakers' attempts to adapt to village life by trying to physically reconnect with it. These performances are meant to bring them closer to their filmed subjects, but they also set them apart by showing the generational and social divide between the elderly villagers and the young filmmakers.

\section{Commemorating the famine and helping villagers}

As the project evolves year after year, more attention is devoted to practical actions in the villages. After visiting elderly living in very difficult conditions without much help to supervise their health, to buy and cook food, or to wash and get properly dressed, the filmmakers have progressively changed their roles. Besides interviewing them, they also decided to act as social workers or caring family members. Zhang Mengqi films herself tending to her melancholy grandfather. She also tries to set up an electrical wire for an old lady who lives in a shack next to the home of her negligent children. In line with Caochangdi Workstation's promotion of autonomy of agency, the participants are striving for "changing things starting from themselves" as much as for the old people fund and the collecting of trash. The recording of unofficial history on the Great Famine has therefore led to these concrete actions, including one targeting the memory of the famine itself: the setting of memorial stones commemorating the villagers who starved to death. ${ }^{(47)}$ Through the filmmakers' lens, this process becomes a collective investigation to find out the names, dates, and circumstances of unrecorded death thanks to information provided by the old people. Money is collected on a voluntary basis among the villagers, who discuss the purchase of a stone, the inscription, and conduct a ceremony. Zou Xueping, for instance, teams up with her niece and other village girls and trains them to film. She organises for them a restitution screening of her first documentary The Starving Village (Ji'e de cunzi, 2010, 76 min.) and

47. This initiative, which materialises the aim of the FMP and works directly against the lack of recognition of the famine, is not unique, since some memorials have been privately raised across China. See Zhou Xun, Forgotten Voices of Mao's Great Famine, 1958-1962: An Oral History, New Haven, Yale University Press, 2013, p. 274. On the revival of rituals for the dead of the Great Leap famine, see Stephan Feuchtwang, After the Event, op. cit., pp. 92-111 and pp. 209-228. See also Rubie S. Watson, "Making Secret Histories: Memory and Mourning in Post-Mao China," in Rubie S. Watson (ed), Memory, History and Opposition: Under State Socialism, Santa Fe, James Currey Publishers, 1999, pp. 65-84. 

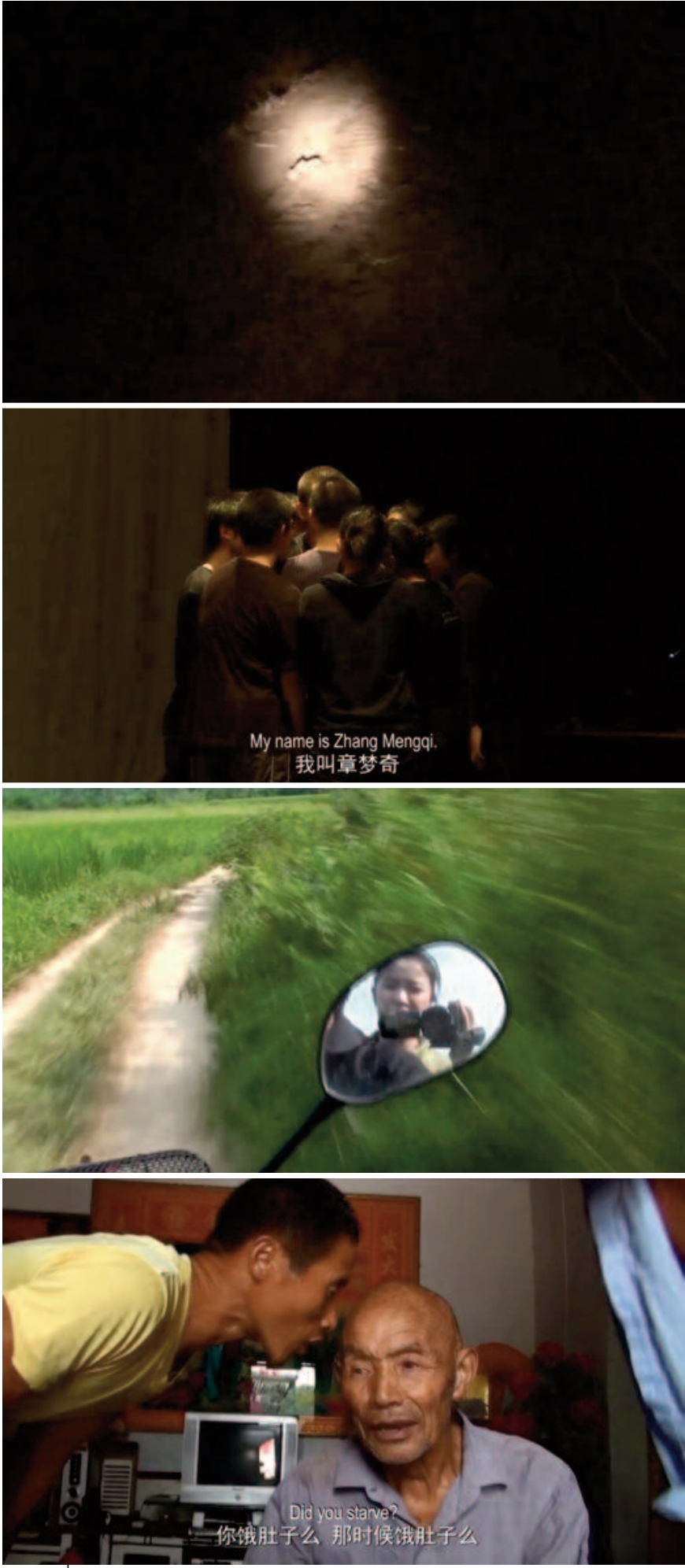

Images 4-A, 4-B, 4-C, 4-D - Introductory sequence of Zhang Mengqi's Self-Portrait: At 47 km (2011, 77 min.). Onsite performance (night walk), onstage performance of selfintroduction, photographic self-portrait, first interview with an interpreter. () Zhang Mengqi

films their reactions. Her second film, Children's Village (Haizi de cunzi, 2012, $85 \mathrm{~min}$.) shows the children visiting and interviewing old people with her, behaving like apprentice journalists and basically performing Zou Xueping's role. Two teams are formed to collect the names and personal particulars to be inscribed on the tombstone. The shooting setting changes as each team uses two cameras, one held by the interviewer, and the other one by her teammate (Zou Xueping or another child) filming the interviewer. Children 's Village is a montage of this various footage. As everyone is taking part in the process, these scenes are characterised by a multiplicity of enunciators, which makes the interviews at times very confused and superficial. On the other hand, it reflects the growing involvement of young people in the project. The participation of children does not really serve an oral history purpose, since the interviews are only short, factual exchanges and not always successful. Rather, this performing process mainly aims at actively transmitting this forgotten history to the younger generation. Even if sequences in other FMP movies also show that the process of setting memorials is not always met with the appropriate solemnity, these experiences and their material traces in the form of films and stones undoubtedly forge a local memory of the famine.

\section{Onsite performances in Zhang Mengqi's films}

As we can see in the case of Zou Xueping's documentaries, filming one's own actions (here, helping elderly or simply interacting with the villagers) necessarily brings about performativity in the form of a mise-en-scène of the self. This type of performance is however significantly different from the blend of performing arts and documentary at work in Zhang Mengqi's films. After graduating from the China Central Minority University's Dance Academy (Zhongyang Minzu Daxue Wudao Xueyuan), she began her performing career in the Living Dance Studio and gradually moved to filmmaking with a first documentary called Self-Portrait with 3 Women (Zihuaxiang he san ge nüren, 2010, 70 min.), related to the theme of the performance piece Report on the Body (Wen Hui, Shenti Baogao, 2003). Although SelfPortrait with 3 Women does not belong to the FMP, it also deals with memory, incorporates performance scenes, and uses a subjective autobiographical diary form useful for discussing her subsequent films. An "existential" documentary, Self-Portrait with 3 Women was prompted by the absence of transmission of female secrets in her family - details about her mother and grandmother's intimate lives. The first-person narration follows Zhang Mengai's childhood memories and weaves them together with her mother's and grandmother's as the three women reunite for Chinese New Year. The presence of the maternal grandfather - with whom the grandmother frequently argues - reflects on the absence of Zhang Mengqi's own father. A dancer's self-portrait, the film is framed by performance scenes acting as reminders of her identity. The film starts on a stage, and excerpts from the show Remembering 1, which she performs herself, are edited into the movie. Projected on Zhang Mengqi's dancing body is a video shot by her mother in which she talks to the camera addressing her daughter in a very personal tone. From the mother's intimate stories emerge historical memories as she discusses the idea of reports and self-critics.

The mirror-like dispositive, the subjective perspective and the emphasis on performing scenes expressing identity and memories are later used in Zhang Mengqi's FMP films focusing on her family's paternal side. They are filmed in her estranged father's native village in Hubei, where she has no childhood memory and almost no roots, since her father left the village early in his life. Her FMP films are still "self-portraits," even though they include several interviews with elderly people about their experience of the famine or other historical events, and more and more sequences in interaction with the village inhabitants. This self-centred perspective is surprising 
at first for films dealing with such heavy historical topics, but instead of denoting narcissism, I would argue that it is aimed at engaging the audience - especially a younger, urbanised, and educated one like the filmmaker's.

Compared with others FMP filmmakers, Zhang Mengqi uses an even more diversified range of performance and performativity. Besides the performative mode, she also edits onstage and onsite performances conducted in the village, alone or with children with whom she engages in games and physical exercises. The editing of the introductory sequence of Self-portrait: at $47 \mathrm{~km}$ (Zihuaxiang: 47 gongli, 2011, $77 \mathrm{~min}$.) (Images 4-A, 4-B, 4-C, and 4-D) links together night shots filmed in a "subjective camera" mode of her feet walking in the village empty streets. This sort of onsite performance, aimed at appropriating the space of the village, is connected by the editing to an onstage performance, an excerpt of Remembering II: Hunger (Huiyi er: ji'e). In this subjective representation of the collected memories, Zhang Mengqi states her identity while being carried by a group of performers. Slowly emerging from their arms as the scene unfolds, she becomes visible and identifiable both visually and through her monologue. This performed self-introduction becomes a photographic self-portrait in the next shot. It is an insert of her face reflected on the rear mirror of the motorcycle driving her into the village. Then, a series of short interviews takes place in different villagers' houses. These clumsily filmed dialogues are only made possible by villagers acting as intermediaries and interpreters, and foreground her outsider status. Rather than delivering any significant information on the famine, this sequence shows how much her identity is an obstacle to conducting this work, as well as the shortcomings of amateur oral history projects. In its "oral history" sequences, this film displays mostly failed attempts to reconnect with the past and with the countryside, as much on the side of the filmed subjects, who do not remember, as on the side of the filmmaker, who is not yet able to communicate with them. Yet, this failure possesses heuristic value: in her subsequent films, Zhang Mengqi seems more in peace with her identity, she has changed her approach to the villagers, who have in turn become used to her presence, and valuable conversations between filmed subjects and filmmaker appear. The succession of performances and self-portraits in the first film reflects Zhang Mengqi's attempts to find her "position" (weizhi) in the village and towards history, a concern she has raised during discussions, and relates to her performer's background and the set of questions on space and movement that necessarily emerge for her. It is also connected to her personal identity quest regarding her family, and her stand towards the villagers' history. Besides being a tool of self-exploration and spatial appropriation, performance also clearly has a connecting function between various places and enunciators in the abovementioned sequence. It is performance in one form or another that logically brings together spaces kilometres away, such as the Beijing performance venue and the Hubei village, and various facets of the filmmaker, performing, filming, or engaging with her family's and other people's past. Performance works here as an editing device, a connecting link (or raccord) carrying both meaning and formal value.

In the more recent Self-portrait: Dreaming at $47 \mathrm{~km}$ (2013), Zhang's focus has slightly shifted from collecting villagers' memories to recording their everyday lives and assisting them, often very physically, in their daily tasks. Zhang Mengqi has similarly moved from a self-portrait framework to an indirect depiction of herself through her interactions in the village, perhaps because she no longer needs to define her own identity. The on-site performances inspired by the success of her village library are numerous and more elaborated than in the above example, and they no longer refer to
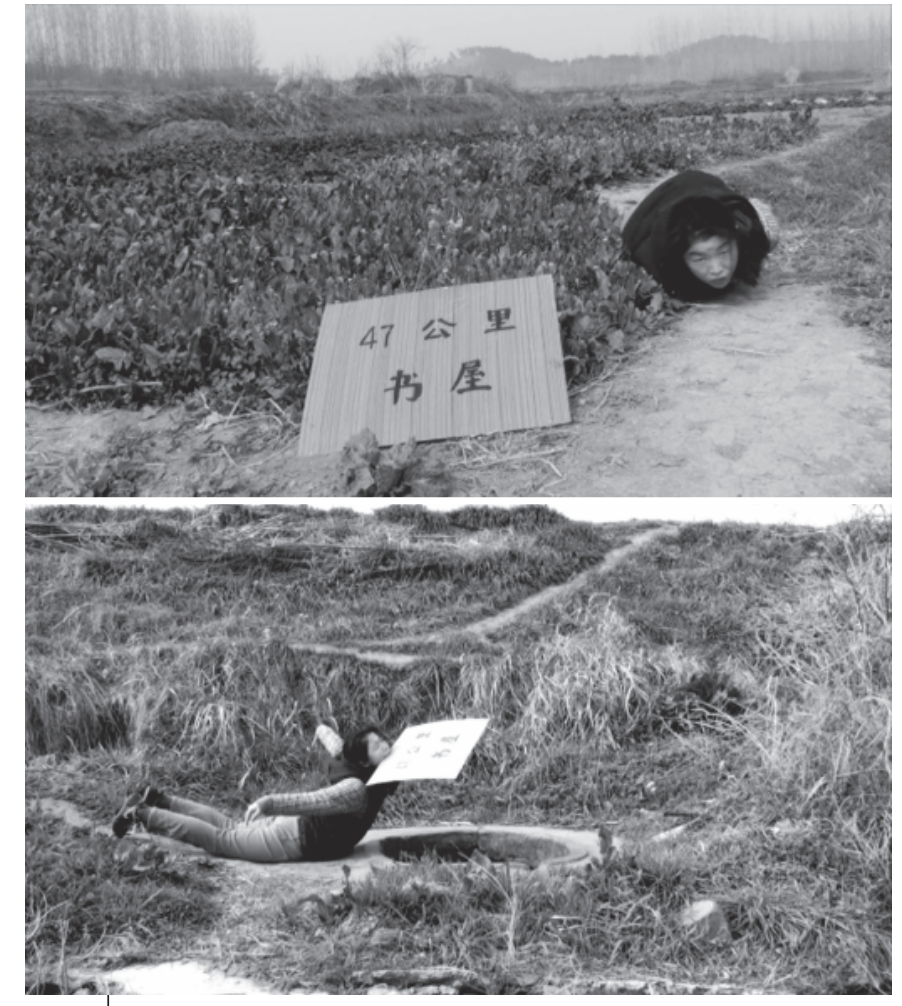

Images 5-A, 5-B - Onsite performances in Self-portrait: Dreaming at 47 km (2013, 77 min.). ( Z Zhang Mengqi

onstage performances. In mute, black-and-white sequences placed regularly in the documentary, she films herself carrying the library sign in a series of grim tableaux, sitting in the middle of a field, or crawling on the ground (Images 5-A and 5-B). The "dream" sequences are usually introduced by uncanny shots of barking dogs leading the filmmaker into isolated places, the animals' attitude reflecting a residual hostility perceptible in the village. In two instances, the performances consist of disabling herself from the use of her limbs, something that calls to mind the decaying bodies of the elderly villagers, and the viewer can sense that her dream of transforming the village through her actions is becoming a highly emotional nightmare. In the last sequence, she is lying on her stomach on the ground, the library sign in her mouth. Using her arms as wings, she attempts to lift her body off the floor and her head out of a well, as if rescuing the sign from a suicide attempt. These onsite performances express her own feelings of helplessness towards the inexorable passing of the elderly, and also her concerns regarding the progress of the FMP, topics she has openly raised in workshops and discussions. As the project includes more and more practical actions aimed at helping the villagers, the filmmakers' roles have taken a turn that brings them even closer to social and familial realities harsher and greater than their own capabilities as occasional visitors. Here, the performance sequences possess a clear expressive function - that of translating the filmmaker's feelings of despair - and edited into various points of the film, they also provide a much-needed counter-story to the otherwise positive changes she brings to the village.

\section{Conclusion}

This overview of the various and at times entangled performative elements in this body of films has highlighted practical uses of performative methods to retrieve and convey the subjective memory of the Great 
Famine. Even if in these films the memory is not directly transmitted through performances or thanks to the performative mode, in contrast to films relying on re-enactment such as The Act of Killing or S21, these elements play a crucial role in many regards. First, performativity helps trigger the act of remembrance during the shooting process by creating intimacy between witnesses and filmmakers. Performativity allows the sharing of past personal experiences and also proves very fruitful in actively involving others in this process. It bridges the generational gap between the interviewed elderly and the filmmakers, and between the filmmakers and the younger generation. At the editing stage, performance and performativity provide transitions and links between sequences, helping to identify the position of filmmakers and protagonists and their relation to the memory of the Great famine. The self-introductions, both in the onstage performances and in the films, as well as the films' status as self-portraits or diaries, facilitate an understanding of not exactly the historical period itself, but rather how younger generations can relate to it, and the role history can play today in the construction of their own identity. So, more than just a filming mode or device, performativity is here a practical process that proves efficient in the long run, first for collecting memories, and second for transmitting them or acting on them. As for documentaries made by other filmmakers worldwide, the use of performativity is due to the difficulty of retrieving witnesses' personal memories, but also and more importantly in this case, to the lack of official recognition of the victims, a situation weighing on the relative amnesia of the filmed subjects and, for some of them, on their discourse and outlook on the period.

The relative silence regarding the Great famine also explains the need for the FMP participants to embody the testimonies and turn the interviews, as well as their experiences in the villages, into gestures, acting scenes, or performing acts. Contrary to purely oral history projects, the FMP performance pieces consist of reinterpreting the villagers' memories, as if the spoken word of the witnesses were not enough to grasp the significance of their testimony. Indeed, during discussions, Wu Wenguang often underlines the importance of working on onstage performances to "put together the various pieces of the project," from the lengthy oral history transcriptions, to the subjective experiences of the contemporary countryside. For Zhuang, the on-stage performances "are designed not so much to restage survivors' traumatic memories and/or the already-collected and compiled (rural) 'sufferings' as to transmit these remembered sufferings onto the performers themselves, both somatically and symbolically." (48) Similarly, but through different means, there is a need for theatricality and performativity in the documentaries. The films emphasise the dissemination of historical awareness, since they are first and foremost the very recording of this transmission process between the witnesses, the filmmakers, and other protagonists. But if the performance pieces stage the appropriation of memories by another generation and therefore constitute an interpretation both in the sense of theatrical acting and reading, the films' emphasis on practical actions and the processes of conducting interviews, social work, setting memorials, and so on is aimed at triggering the audience's impulse to act similarly. Thus, the performativity involved in the films is akin to activism, carried out through the educational function of exemplarity, as with the efficacy of emotions, staged, performed, or narrated through the filmmakers' subjective lens. These films' subjectivity and theatricality constitute an attempt to create a transmission method based on affect and identification. Instead of using a didactical narrative backed by facts and testimonies, the FMP makes use of a combination of documentation, performance, participation, and virality. This choice of devices and work method has a lot to do with Wu Wenguang's definition of documentary as an everyday recording and "writing" practice open to all and allowing a personal reflection on contemporary social issues, without the strictures of commercial film formats. Therefore, the identity quest performed by the filmmakers cannot be considered a selfcentred individual pursuit. Their subjective perspective on the countryside reflects their concern of providing a personified approach to historical memory capable of raising the interest and agency of others. The educational ambition of the project and its targeting of a young audience are ultimately the most important missions and successes of the Folk Memory Project.

I Judith Pernin is a postdoctoral researcher at the CEFC working on Chinese documentary film, affiliated with the Institut d'Histoire du Temps Présent (CNRS).

CEFC, 20/F Wanchai Central Building, 89 Lockhart Road, Wanchai, Hong Kong (judithpernin@gmail.com). 